\title{
Pääkirjoitus
}

\section{Muutosta ja kasvua}

\author{
Niina Hämäläinen ja Nika Potinkara
}

$\mathrm{K}$ ukat ovat huvituksia, jotka sivistävät ihmistä - näin kertoo ensimmäinen suomeksi ilmestynyt puutarhakirja Kaswutarha-kirja Rahwaan hyödyksi (Eneroth 1860). Opaskirja sisältyy Eloren tässä numerossa julkaistavan artikkelin aineistoon. Myös Elore on huvitus, joka hyödyttää lukijaa, sillä nytkin lehdessä on useita kiinnostavia ja ajankohtaisia kirjoituksia.

Kahden teemanumeron jälkeen kevään 2019 lehti on vapaateemainen. Lehdessä on yksi referoitu artikkeli, yksi katsaus sekä lukuisia ajankohtaistekstejä ja kirja-arvioita. Varhaisia puutarhaoppaita käsittelevä Marjukka Piiraisen artikkeli koskettelee monin osin folkloristiikan alan keskeisiä kysymyksiä. Puutarhaoppaat valistivat tavallista kansaa mutta myös määrittelivät käsitystä hyvästä elämästä, johon kuuluivat muun muassa ahkeruus ja raittius. Puutarhaoppaat liittyvät myös suullisen ja kirjallisen kulttuurin väliseen rajankäyntiin. Ensimmäisten oppaiden ilmestymisen aikaan monikaan suomea äidinkielenään puhuva ei välttämättä osannut sujuvasti lukea - oppaat kirjoitettiinkin selkeästi, jotta mahdollisimman monen pääsy puutarhanhoidon maailmaan olisi taattu.

Matka puutarhaoppaista lehden katsausartikkelin aiheeseen saattaa näyttää pitkältä, mutta ei sitä välttämättä ole. Karoliina Maanmielen katsaus pureutuu muistelukirjoituksiin suomalaisten mielisairaalakokemuksista keskittyen erityisesti muistelijoiden kokemaan häpeään; katsauksessa tarkastellaan sekä potilaiden että heidän läheistensä kertomuksia ja pohditaan muistelukerronnan mahdollisuuksia häpeän lievittäjänä. Siinä missä varhaiset puutarhaoppaat piirtävät kuvaa ihanteellisesta kansalaisesta, mielisairaala-aineisto avaa hyvään elämään ja kansalaisuuteen liittyviä käsityksiä erilaisuuden ja toiseuden näkökulmista.

Elore on siirtynyt tämän vuoden puolella yhä yhtenäisempään julkaisemiseen. Toimitusprosessi hoidetaan nyt Tieteellisten Seurain Valtuuskunnan (TSV) hallinnoiman Open Journal Systemin (OJS) kautta, ja lehden vanhat verkkosivut ovat poistuneet käytöstä: niin Eloren julkaistut numerot kuin kirjoittajaohjeetkin löytyvät nykyään osoitteesta journal.fi/elore. Lehtiarkiston siirtämisen myötä kaikki vuosien 1994 ja 2018 välillä ilmestyneet yli 1200 kirjoitusta ovat nyt turvallisesti TSV:n hallinnoiman alustan suojissa.

Kaikilla Eloressa ilmestyneillä teksteillä on nyt myös DOI-tunnus. DOI eli Digital Object Identifier on elektronisille aineistolle annettava pysyvä tunniste. Jos vaikkapa julkaisuluettelostasi löytyy Eloressa ilmestyneitä artikkeleita tai muita kirjoituksia, vanha verkko-osoite kannattaa 
korvata DOI-tunnuksella tai https://doi.org-alkuisella osoitteella. Omat ja muiden tekstit löydät Eloresta helpoimmin hakutoiminnolla.

Kevään numeron myötä myös Eloren toimituskunta on jossain määrin vaihtunut. Olemme saaneet viisi uutta toimittajaa artikkeli- ja ajankohtaistoimituksiin. Tervetuloa Tero Ahlgren, Anna Hynninen, Tuukka Karlsson, Karin Sandell ja Eija Stark! Jotkut pitkäaikaiset toimittajat, kuten päätoimittajanakin työskennellyt Taija Kaarlenkaski sekä kirja-arviotoimittaja Konsta Kajander, ovat etsiytymässä kohti uusia haasteita, ja Elore kiittää molempia hyvästä lehtityöstä. Tieteellisen lehden toimitustyöstä saattaa olla huvin lisäksi myös hyötyä: Eloren entisestä päätoimittajasta Karina Lukinista on tullut Studia Fennica Folkloristican päätoimittaja. Elore onnittelee Karinaa lämpimästi.

Kesä on tullut ja nyt myös elorelaisilla on aikaa rentoutua ja nauttia valosta. Kiitos kaikille kevätnumeroon kirjoittaneille, toimittajille, vertaisarvioijille, toimitussihteerille ja kielentarkistajalle! Aurinkoista kesää ja nautinnollisia lukuhetkiä Eloren parissa!

\section{Kirjallisuus}

Eneroth, Olli. 1860. Kaswutarha-kirja Rahwaalle: Kaswutarha-kirja Rahwaan hyödyksi. Suomentanut F. v. P. Turku: J. W. Lilljan kirjapaino. 